\title{
Impact of Weather Parameters on Seasonal Incidence of Diseases and Enemies in Apis cerana F.
}

\author{
Nitika Negi ${ }^{*}$, Meena Thakur, Harish Kumar Sharma and Panma Yankit \\ Department of Entomology, Dr. Y. S. Parmar University of Horticulture and Forestry, Nauni, \\ Solan, (HP), 173230, India \\ *Corresponding author
}

\begin{tabular}{|l|}
\hline K e y w o r d s \\
$\begin{array}{l}\text { Apis cerana, } \text { Incidence, } \\
\text { Bee disease, Bee enemies, } \\
\text { Tropilaelaps clareae }\end{array}$ \\
\hline Article Info \\
\hline $\begin{array}{l}\text { Accepted: } \\
\text { 04 November } 2018 \\
\text { Available Online: } \\
\text { 10 December } 2018\end{array}$ \\
\hline
\end{tabular}

A B S T R A C T

Studies on impact of weather parameters on seasonal incidence of diseases and enemies in Apis cerana were conducted at A. cerana apiary maintained by Department of Entomology, Dr. Y. S. Parmar University of Horticulture and Forestry, Nauni, Solan during April, 2016 to March, 2017. European foulbrood disease incidence was statistically maximum (23.00\%) in the month of July, 2016 when temperature, relative humidity and rainfall were high. Maximum incidence of Thai sacbrood disease was recorded during the month of May, 2016 (2.33\%) when humidity was low (46.00\%). No incidence of Nosema was observed during the study period. Thus the external weather parameters also influenced the disease incidence in the hive of A. cerana. The incidence of ectoparasitic mite (Tropilaelaps clareae) was maximum in the month of September, 2016 (10.00\%), whereas, no incidence of Varroa destructor was observed. No incidence of wasps was recorded on A. cerana apiary, whereas wasps were found visiting A. mellifera apiary and maximum incidence $(12.54 \pm 0.88)$ was recorded during the month of June, 2016.T. clareae incidence was positively correlated with temperature and relative humidity and negatively correlated with rainfall, whereas, wasp incidence was positively correlated with all the weather parameters.

\section{Introduction}

Honey bees are social insects which are directly beneficial to man. Honey bees provide valuable products like pollen, royal, jelly, bees wax, propolis, venom, besides providing the main product honey. Honey bees play vital role in agriculture by assisting in pollination of a wide variety of crops and help in maintaining the biological diversity (Johannesmeier and Mostert, 2001). Honey bees being ectothermic, are unable to control internally their body temperature with change in the ambient temperature and hence environmental factors such as ambient air temperature, solar radiation etc. significantly influence their body temperature (Reddy et al., 2012). In normal colonies, the brood-nest temperature is maintained constant around $32^{\circ} \mathrm{C}$. During nectar and pollen foraging, honey bees are exposed to broad range of ambient temperature which affect their thermoregulatory ability (Kovac and Stabentheiner, 2011). At present four species of the genus Apis viz., Apis cerana F., Apis mellifera L., Apis dorsata F. and Apis florea F. 
are known for honey products and pollination in crops. Of these, A. cerana, A. dorsata and A. florea are native to India. The Indian hive bee, A. cerana is found almost in all parts of the country, except the cold and hot desert because of non-availability of flora. A change in climatic conditions is bound to have an impact on the survival of honey bee species that are closely associated with their environment. Migration and changes in their lifecycle and behaviour could help them to survive in new biotopes. Honey bees will also need to adapt to a whole array of predators, parasites and pathogens surrounding them. Not only will the relationships between hosts and parasites change, honey bees will have to cope with new stresses arising from tradefacilitated transfers of pathogens among honey bee species.

Honey bee diseases like American foulbrood, European foulbrood, Chalk brood, Sacbrood, Thai sacbrood virus, Nosema, Stone brood, Acarine and Varrosis are worldwide known diseases. European foul brood disease is one of the important bacterial diseases which are prevalent throughout the country in A. cerana and A. mellifera (Rao et al., 2011). Foulbrood disease one of the most destructive diseases of the honey bee in all apiaries during autumn and winter however; it is spread sometimes during spring. EFB disease is a bacterial disease that effects honey bee larvae before the capped stage, it spread in all districts during spring and summer (Fathy et al., 2012).

The TSBV disease incidence decreased in the month of April when the mean maximum temperature $\left(34.3^{\circ} \mathrm{C}\right)$ was high while the relative humidity (RH 65\%) and rainfall (62.7 $\mathrm{mm}$ ) were low (Aruna et al., 2016). Nosema disease is also most widespread in India. About 100 mostly harmless mite species are associated with honey bees but Acarapiswoodi, Varroajacobsoni, and Tropilaelaps clareae are the main pests of honey bees. Other enemies like wasps, birds and wax moths etc. are also reported to cause damage to honey bee colonies.

\section{Materials and Methods}

Studies impact of weather parameters on seasonal incidence of diseases and enemies in A. cerana F. were conducted during April, 2016 to March, 2017 in A. cerana F. colonies maintained by the Department of Entomology, Dr. Y.S. Parmar University of Horticulture and Forestry, Nauni, Solan, Himachal Pradesh, which is situated at $33.3^{\circ} \mathrm{N}$ latitude, $70.70^{\circ} \mathrm{E}$ longitude and $1256 \mathrm{~m}$ above mean sea level (amsl) average climatic conditions of Himachal Pradesh.

The incidence of diseases occurring in the colonies was recorded at monthly interval. Three colonies were selected for the study to observe the incidence of brood and adult diseases. 100 brood cells in each of selected colony were examined for recording incidence of brood diseases (European foulbrood and Thai sacbrood) and per cent brood infection calculated as follow:

Infected brood cells $\%$ brood infection in the colony $=$------- $\mathrm{x} 100$

Total brood cells

Adult disease (Nosema sp.) was visualized by presence of crawler bees and bees with swollen abdomen. The incidence of mites (Tropilaelaps clareae and Varroa destructor) in brood and adults was recorded by visual examination of brood cells. Bottom debris was also examined for presence of mites under microscope. Incidence of wasps was recorded by counting the number of wasps visiting experimental colony of $A$. cerana. The data collected from experiments conducted in field conditions was statistically analysed with the help of analysis of variance in RBD (Panse and Sukhanatme, 1967).

Results and Discussion 


\section{Incidence of diseases}

The incidence of European foulbrood disease was statistically maximum in the month of July, 2016 (23.00\%) when temperature, relative humidity and rainfall were $24.00{ }^{\circ} \mathrm{C}$, 82.00 per cent and $151.90 \mathrm{~mm}$, respectively, followed by 5.00 per cent in the month of April, 2016 which was statistically at par with all other months except December, 2016, February and March, 2017 (Table 1 and Fig. 1). European foulbrood disease is reported to appear usually in spring and first half of summer season but in recent times its occurrence has not shown a clear dependence on season (Russenova and Parvanov, 2005). In a study conducted by Brar (2016) on European foulbrood incidence of A. mellifera in the same apiary as in present study, maximum incidence of European foulbrood disease (29 $\%$ ) was observed in the month of September, 2015 which was statistically at par with the month of July (26\%) which supports the present findings.

The minimum incidence of European foulbrood was observed in the month of March, 2017 (0.44\%) values being statistically same when temperature, relative humidity and rainfall were low i.e. $15.35{ }^{\circ} \mathrm{C}, 44.50$ per cent and $33.20 \mathrm{~mm}$, respectively. No incidence of European foulbrood was observed in the month of December, 2016 in A. cerana colonies in the year. Generally during winter months, less number of available nurse bee's resulted in production of less amount of glandular food which caused the diseased larvae to appear starved and was easily detected and removed by bees. Similarly, Verma (2005) also reported minimum (4.5\%) incidence of European foulbrood disease in the same apiary of A. cerana colonies during March, 2004. Incidence of European foulbrood had positive correlation (nonsignificant $)$ with temperature $(r=0.427)$, relative humidity $(\mathrm{r}=0.493)$, rainfall $(\mathrm{r}=$
0.474) (Table 2). Positive correlation of incidence of European foulbrood disease in different months of year in relation to bee strength, temperature, rainfall and relative humidity has been reported by Buza and Kovacs (1969).

The data on incidence of Thai sacbrood disease observed in A. cerana colonies varied from 0.23 to 1.07 per cent (Table 1 and Fig. 2). Maximum incidence was observed in the month of May, 2016 (2.33\%) when temperature and rainfall were high and relative humidity was low i.e. 23.55 per cent, 115.00 $\mathrm{mm}$ and $46.00{ }^{\circ} \mathrm{C}$, respectively, which was statistically at par with disease in the month of April, September, 2016, July and January, 2017 that is $1.07,0.70,0.60$ and 0.52 per cent, respectively. Rana (2008) reported incidence of Thai sacbrood disease in A. cerana during the month of May, 2006 with 1.6 to 15.0 per cent brood infection and 20 to 60 per cent colony infection at Nauni, Solan. Whereas, minimum incidence was recorded in the month of November, $2016(0.23 \%)$ when temperature and relative humidity were low i.e. $15.80{ }^{\circ} \mathrm{C}$ and 40.50 per cent, respectively and no rainfall, which was statistically at par with all other months except May, 2016 (2.33\%). Brar (2016) also reported A. mellifera colonies to be free from sac brood disease during July, 2015 to June, 2016 in the same apiary at Nauni, Solan. In spring when brood rearing is at its highest sacbrood disease seemed to spread quickly. The occurrence of sacbrood disease in spring (build- up period) is due to the existence of greater proportions of susceptible young adults and larvae in colonies (Bailey, 1968). Incidence of Thai sacbrood had positive but non-significant correlation with temperature $(r=0.389)$ and rainfall $(r=0.257)$ whereas, negative nonsignificant correlation with relative humidity $(r=-0.166)($ Table 2). 
Fig.1 European Foulbrood infected larvae and prepupae

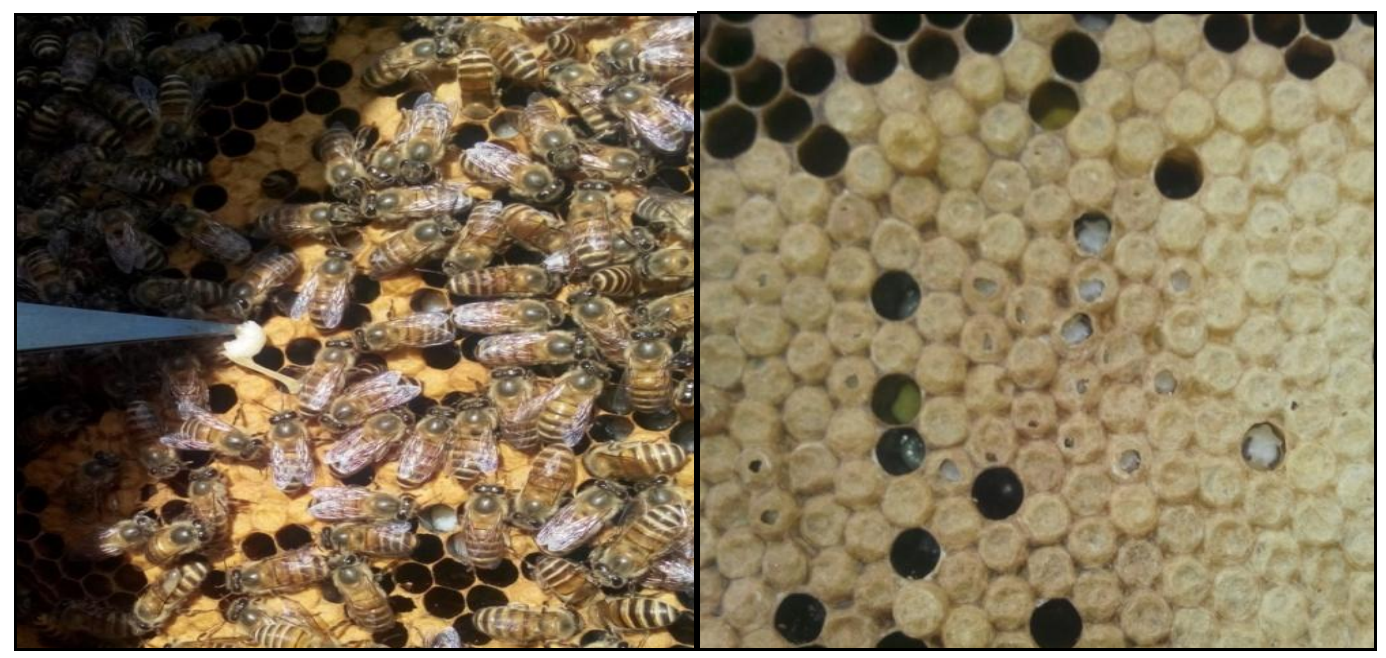

Fig.2 Thai sacbrood infected larvae and prepupae

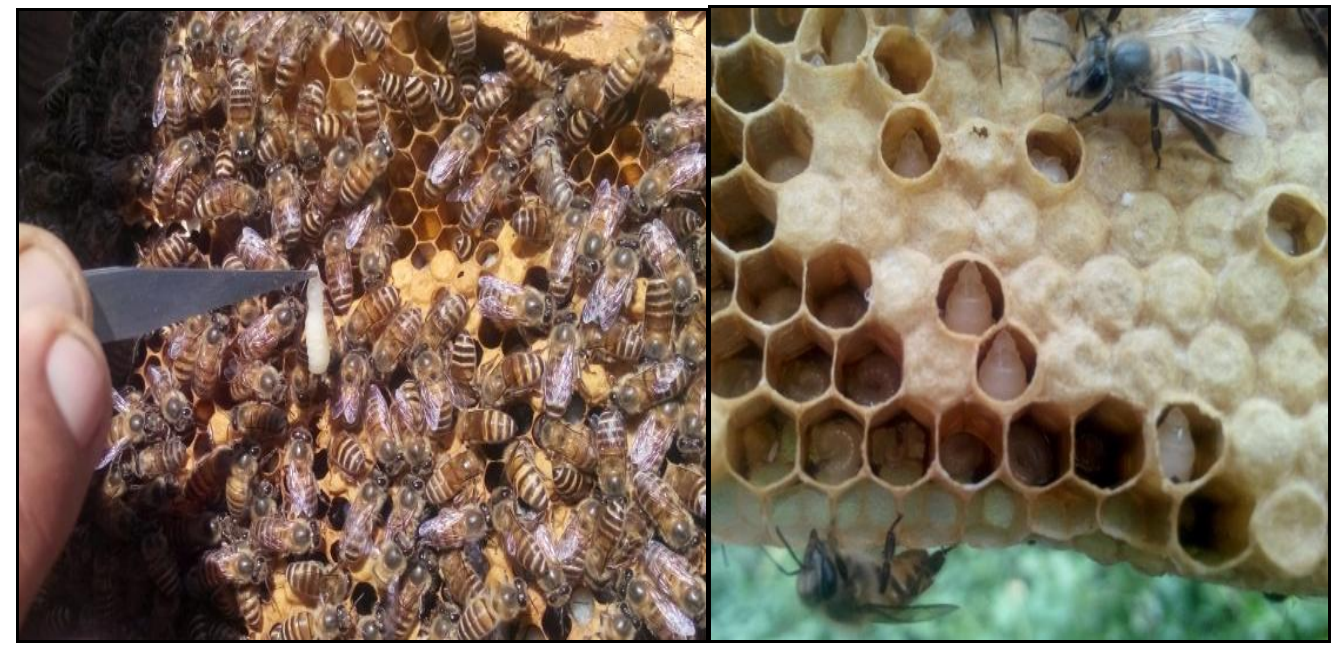

Fig.3 Ectoparasitic mite (Tropilaelaps clareae) on Apis cerana larvae

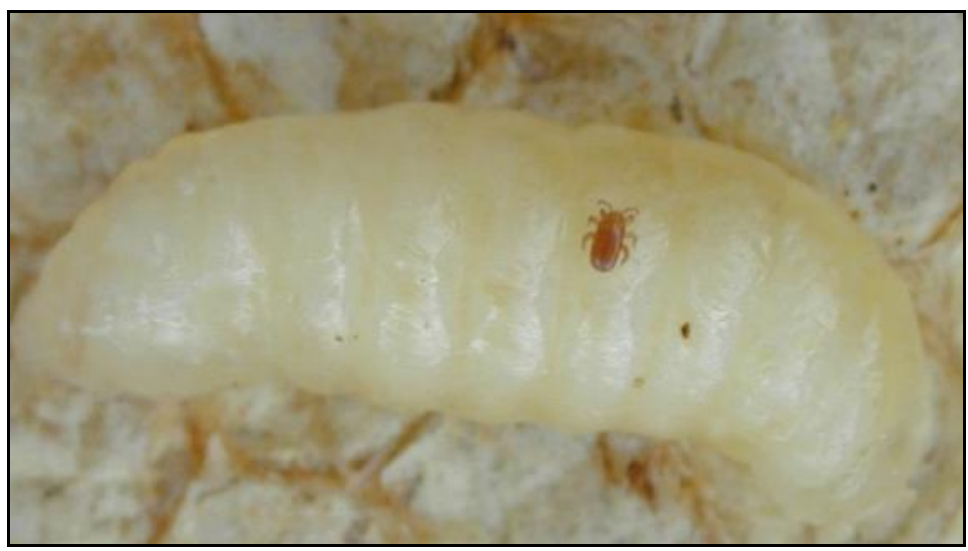


Table.1 Incidence of diseases and enemies in Apis cerana colonies and correlation with weather parameters during April, 2016 to March, 2017

\begin{tabular}{|c|c|c|c|c|c|c|c|c|c|}
\hline \multirow[t]{2}{*}{ Period } & \multicolumn{2}{|c|}{ Incidence $(\%)$} & \multicolumn{2}{|c|}{ Brood infestation ${ }^{\#}(\%)$} & \multicolumn{2}{|c|}{ Wasps visits/ day } & \multicolumn{3}{|c|}{ Weather parameters } \\
\hline & $\begin{array}{l}\text { European } \\
\text { Foulbrood }\end{array}$ & Thai sacbrood & $\begin{array}{c}\text { Tropilaelaps } \\
\text { clareae }\end{array}$ & Varroa destructor & Apis cerana & Apis mellifera & Temperature $\left({ }^{\circ} \mathbf{C}\right)$ & $\begin{array}{c}\text { Relative } \\
\text { humidity }(\%)\end{array}$ & Rainfall (mm) \\
\hline April, 2016 & $\begin{array}{c}5.00 \\
(2.41)^{*}\end{array}$ & $\begin{array}{c}1.07 \\
(1.41)^{*}\end{array}$ & $\begin{array}{c}1.33 \\
(1.41)^{*}\end{array}$ & - & - & $1.8 \pm 0.32$ & 21.45 & 44.50 & 25.60 \\
\hline May & $\begin{array}{c}3.50 \\
(2.09)\end{array}$ & $\begin{array}{c}2.33 \\
(1.73)\end{array}$ & $\begin{array}{c}5.00 \\
(2.00)\end{array}$ & - & - & $4.45 \pm 0.58$ & 23.55 & 46.00 & 115.00 \\
\hline June & $\begin{array}{c}0.85 \\
(1.36)\end{array}$ & $\begin{array}{c}0.33 \\
(1.14)\end{array}$ & $\begin{array}{c}0.00 \\
(1.00)\end{array}$ & - & - & $12.54 \pm 0.88$ & 24.50 & 65.00 & 118.90 \\
\hline July & $\begin{array}{l}23.00 \\
(4.65)\end{array}$ & $\begin{array}{c}0.60 \\
(1.25)\end{array}$ & $\begin{array}{c}0.00 \\
(1.00)\end{array}$ & - & - & - & 24.00 & 82.00 & 151.90 \\
\hline August & $\begin{array}{c}3.93 \\
(2.18)\end{array}$ & $\begin{array}{c}0.00 \\
(1.00)\end{array}$ & $\begin{array}{c}0.00 \\
(1.00)\end{array}$ & - & - & - & 23.40 & 82.50 & 164.10 \\
\hline September & $\begin{array}{c}1.43 \\
(1.53)\end{array}$ & $\begin{array}{c}0.70 \\
(1.28)\end{array}$ & $\begin{array}{l}10.00 \\
(2.52)\end{array}$ & - & - & $2 \pm 1.46$ & 23.00 & 73.50 & 11.20 \\
\hline October & $\begin{array}{c}3.40 \\
(2.08)\end{array}$ & $\begin{array}{c}0.00 \\
(1.00)\end{array}$ & $\begin{array}{c}0.00 \\
(1.00)\end{array}$ & - & - & $1.3 \pm 2.76$ & 19.50 & 55.00 & 0.00 \\
\hline November & $\begin{array}{c}1.82 \\
(1.65)\end{array}$ & $\begin{array}{c}0.23 \\
(1.10)\end{array}$ & $\begin{array}{c}0.00 \\
(1.00)\end{array}$ & - & - & - & 15.80 & 40.50 & 0.00 \\
\hline December & $\begin{array}{c}0.00 \\
(1.00)\end{array}$ & $\begin{array}{c}0.00 \\
(1.00)\end{array}$ & $\begin{array}{c}0.00 \\
(1.00)\end{array}$ & - & - & - & 13.05 & 46.50 & 8.60 \\
\hline January, 2017 & $\begin{array}{c}1.58 \\
(1.60)\end{array}$ & $\begin{array}{c}0.52 \\
(1.22)\end{array}$ & $\begin{array}{c}0.00 \\
(1.00)\end{array}$ & - & - & - & 9.75 & 69.00 & 122.20 \\
\hline February & $\begin{array}{c}0.67 \\
(1.24)\end{array}$ & $\begin{array}{c}0.00 \\
(1.00)\end{array}$ & $\begin{array}{c}0.00 \\
(1.00)\end{array}$ & - & - & - & 13.65 & 49.00 & 7.60 \\
\hline March & $\begin{array}{c}0.44 \\
(1.18)\end{array}$ & $\begin{array}{c}0.33 \\
(1.14)\end{array}$ & $\begin{array}{c}5.33 \\
(2.04)\end{array}$ & - & - & - & 15.35 & 44.50 & 33.20 \\
\hline C.D 0.05 & 1.07 & 0.51 & 1.81 & & & & & & \\
\hline
\end{tabular}

*Figures in parentheses are square root $(\mathrm{x}+1)$ transformed values, ${ }^{*}$ by visual examination

Table.2 Pearson correlation coefficient (r) between incidence of diseases and enemies with weather parameters during April, 2016 to March, 2017 at Nauni, Solan

\begin{tabular}{|l|}
\multicolumn{1}{|c|}{ Diseases \& Enemies } \\
\hline European Foulbrood \\
\hline Thai Sacbrood \\
\hline Mites \\
\hline Wasps \\
\hline
\end{tabular}

\begin{tabular}{|c|c|c|}
\hline & Weather parameters & Rainfall $(\mathbf{m m})$ \\
\hline Temperature $\left({ }^{\circ} \mathbf{C}\right)$ & Relative Humidity (\%) & 0.47 \\
\hline 0.43 & 0.49 & 0.27 \\
\hline 0.39 & -0.17 & -0.20 \\
\hline 0.26 & 0.00 & 0.26 \\
\hline
\end{tabular}


Rana (2008) reported non-significant correlation of disease incidence in terms of brood infection with ambient temperature $(\mathrm{r}=0.2808)$ and with relative humidity $(\mathrm{r}=$ $0.325)$ for A. cerana.

A. cerana colonies were found to be free from the incidence of Nosema disease in university apiary during the period under study which could be attributed to good colony management. Whereas, Nosema ceranae has been reported infecting $A$. mellifera during 2015 in the university apiary (Divya, 2015). The study indicated that Nosema disease appeared during rainy season (July-August) which peaked during winters (DecemberFebruary). Rana and Katna (2011) also reported 30 per cent bee mortality in 60 per cent A. mellifera colonies due to Nosema disease in northern states of India.

Incidence of ectoparasitic mites (Tropilaelaps clareae and Varroa destructor)

Maximum infestation of $T$. clareae $(10.00 \%)$ was observed (Table 1 and Fig. 3) in the month of September, 2016 when temperature and relative humidity were high and rainfall was low i.e. $23{ }^{\circ} \mathrm{C}, 73.50$ per cent and 11.20 $\mathrm{mm}$, respectively which was statistically at par with infestation of mites in the month of March, 2017 (5.33\%), May (5.00\%) and April, 2016 (1.33\%). Recently studies carried at Nauni, showed maximum (16 mites/colony) and minimum (6 mites/colony) incidence of mite infestation in A. mellifera colonies in the month of June, 2015 and February, 2016, respectively (Brar, 2016). In the present study no incidence of $T$. clareae was observed from June to August, October, 2016 to February, 2017 months of the year. There were high rains during June (118.90 $\mathrm{mm})$, July $(151.90 \mathrm{~mm})$, August, 2016 (164.10 $\mathrm{mm})$ and January, $2017(122.20 \mathrm{~mm})$ which affected the attack of $T$. clareae. Futher, Tropilaelaps cannot stay alive during the winter where colonies are brood less. Whereas, per cent mite infestation was recorded in the month of April, May, September, 2016 and March, 2017 when rainfall was low. No incidence of Varroa destructor was recorded during the period under study, which may be attributed to hygienic and defensive behaviour of the $A$. cerana workers as reported by Rath and Drescher (1990). Tropilaelaps incidence showed positive non-significant correlation with temperature $(\mathrm{r}=0.263)$ and relative humidity $(r=0.003)$ and negative correlation with rainfall $(\mathrm{r}=-0.203)$, though nonsignificant (Table 2.). The observations find support from the study of Camphor and Martin (2009) who reported that incidences of $T$. clareae in A. mellifera vary greatly from year to year and during different months, which may be attributed to fluctuations in temperature, rainfall and relative humidity.

\section{Incidence of enemies}

There was no incidence of wasps in A. cerana colonies (Table 1.) throughout the study period which could be due to the defensive behaviour of $A$. cerana. The observations find support from findings of Ichino and Okada (1994) who observed that the workers of $A$. cerana japonica showed a distinct balling reaction against workers of the predatory hornet (Vespa simillimaxanthoptera), killing the hornets by heat and suffocation generated inside the ball. The present observations are in agreement with the studies conducted by Abrol (2006), who reported killing of 4 to 15 wasps by $A$. cerana during different days with an average of $10.00 \pm 2.77 /$ day as compared to A. mellifera where 0 to 3 wasps were killed with an average of $0.95 \pm 0.95 /$ day. In earlier studies Muzaffar and Ahmad (1986) reported that wasps inflicted heavier damage to $A$. mellifera colonies as compared to A. cerana as the later species defended strongly against the wasp attack. Whereas, visits of wasps both 
V.magnifica and V.auraria in A. mellifera apiary, which is nearby to the A. cerana apiary of the university has been observed. The number of wasp visits in A. mellifera apiary varied from $1.3 \pm 2.76$ to $12.54 \pm 0.88$ (Table 1).

The wasps appeared in the month of April (1.8 \pm 0.32$)$, May $(4.45 \pm 0.58)$ and June $(12.54 \pm 0.88)$ and again noticed visiting apiary in September $(2 \pm 1.46)$ and October $(1.3 \pm 2.76)$ months at Nauni. Maximum incidence $(12.54 \pm 0.88)$ was recorded in the month of June when temperature, relative humidity and rainfall were high i.e. $24.50{ }^{\circ} \mathrm{C}$, 65.00 per cent and $118.90 \mathrm{~mm}$, respectively followed by May, 2016 (4.45 \pm 0.58$)$, whereas, no visits were observed during November, 2016 to March, 2017 in University apiary.

Similar results were reported by Ranabhat and Tamrakar (2008) who reported peak populations of wasps (Vespa velutine and Vespa bicolor) during August to September at Nepal in A. cerana colonies. Further, in their study they also observed minimum population of wasps in January and February months which indicates that the activity of wasps is reduced in cold climatic conditions. In an study on wasp incidence at Nauni, Solan (Brar, 2016), the incidence of V.auraria in A. mellifera was found maximum in September $(366.23+30.38 /$ day) and no visits of wasps were observed during December, 2015 to March, 2016 due to low temperature.

Incidence of wasps showed positive nonsignificant correlation (Table 2.) with temperature $(\mathrm{r}=0.507)$, relative humidity $(\mathrm{r}=$ $0.054)$ and Rainfall $(r=0.259)$.

A positive correlation of number of $V$. auraria and Vespa mandariana with temperature and relative humidity in honey bee colonies was established by Sharma and Mattu (2014).

\section{Acknowledgement}

Authors are thankful to theauthorities of Dr Y S Parmar UHF, Nauni, Solan, Himachal Pradesh for providing necessary facilities. Financial assistance from ICAR, New Delhi through Project Coordinator, AICRP (Honey Bees \& Pollinators) is also duly acknowledged.

\section{References}

Abrol, D. P. 2006. Defensive behaviour of Apis cerana F. against predatory wasps. Journal of Apicultural Science.50:39-46.

Aruna, R., Srinivasan, M. R., Selvarajan, R., Subramanian, S. and Thakur, R. K. 2016. Epidemiology of the Thai sacbrood virus disease attacking Indian honey bee Apis cerana indica $\mathrm{F}$. and morphological characterization of the virus particle using transmission electron microscope. Madras Agriculture Journal. 103(1-3): 51-56.

Bailey, L. 1968. Honey bee pathology, Annual Review Entomology, 13: 191-212.

Brar, A. S. 2016. Seasonal incidence of diseases and enemies in Apis mellifera L., M.Sc. Thesis. Department of Entomology and Apiculture, Dr. YS Parmar University of Horticulture and Forestry, Nauni, Solan. $69 \mathrm{p}$.

Buza, L. and Kovacs, F. 1969. Occurrence of European foul brood and its control. HungaryMcheszet. 17: 123-124.

Camphor, E. S. and Martin. 2009. Population of Tropilaelaps clareae mites in Apis mellifera colonies in Pakistan. Journal of Apicultural Research and Bee World. 48: 46-49.

Divya, 2015. Studies on Nosema disease of Apis mellifera L., M.Sc. Thesis. Department of Entomology and Apiculture, Dr. YS Parmar University of Horticulture and Forestry, Nauni, Solan. $54 \mathrm{p}$.

Fathy, H. M., Hala, A. K., El-Serafy, and Mandouh, D. 2012. Survey of American 
and European foulbrood disease on honey bee colonies in Dakahlia governorate. Journal of Plant Protection and Pathology. 3: 319-325.

Ichino, H. and Okada, I. 1994. Japanese honey bees living in hornet nest. HoneybeeScience. 15: 123-124.

Johannesmeier, M. F. and Mostert, A. J. N. 2001. Crop pollination. In: Beekeeping in South Africa. Pretoria Agricultural Research Council, South Africa 235-250.

Kovac, H. and Stabentheiner, A. 2011. Thermo regulation of foraging honey bees on flowering plants: seasonal variability and influence of radiative heat again. Ecological Entomology. 36: 686-699.

Muzaffar, N. and Ahmad, R. 1986. Studies on hornets attacking honeybees in Pakistan. Journal of Agriculture Research. 7: 5963.

Panse, V. G. and Sukhanatme P. V. 1967. Statistical method for agriculture workers", Indian Council of Agricultural Research, New Delhi.

Rana, B. S. and Katna, S. 2011. Incidence of Nosema disease in Apis mellifera L. of the North India. Insect Environment. 17: 143144.

Rana, R., 2008. Studies on Thai sacbrood and sacbrood diseases of hive bees, Ph.D. Thesis. Department of Entomology and Apiculture, Dr. YS Parmar University of Horticulture and Forestry, Nauni, Solan. 61.

Ranabhatt, N. B. and Tamrakar, A. S. 2008. Study on seasonal activity of predatory wasps attacking honeybee Apis cerana Fab. Colonies in southern belt of Kaski District, Nepal. Journal of Natural History Museum. 23: 125-128.
Rao, K. M. 2009. Molecular characterization of Melissococcus plutonius of hive honey bees and its control with antibiotics, Ph.D. Thesis. Department of Entomology and Apiculture, Dr. YS Parmar University of Horticulture and Forestry, Solan. 97.

Rao, K. M., Rana, B. S., Chakravarty, S. K., Katna, S. and Sharma, A. 2011. Characterization of Melissococcus pluton from European Honey bee (Apis mellifera L.) of North - West Himalayas. International Journal of Science and Nature. 2: 632-638.

Rath, W. and Drescher, W. 1990.Response of Apis cerana F. brood infested with Varroajacobsoni Oud and infestation rate of colonies in Thailand.Apidologie.21:311-321.

Reddy, P. V. R., Veghese, A., Varun, V. and Rajan, V. 2012. Potential impact of climate change on honey bees (Apis spp.) and their pollination services. Pest Management of Horticultural Ecosystem.18:121-127.

Russenova, N. and Parvanov, P. 2005. European foulbrood disease- aetiology, diagnostics and control. Trakia Journal of Sciences.3:10-16.

Sharma, V. and Mattu, V. K. 2014. Bioecological studies on Vespa species in honeybee colonies of Himachal Pradesh, India. American Multidisciplinary International Research Journal. 2: 14-15.

Verma, V. P. S. 2005. Etiology of foulbrood disease of Apis cerana and in vitro evaluation of some antibiotics, M.Sc. Thesis. Department of Entomology and Apiculture, Dr. Y.S. Parmar University of Horticulture and Forestry, Solan. Pp. 41.

\section{How to cite this article:}

Nitika Negi, Meena Thakur, Harish Kumar Sharma and Panma Yankit. 2018. Impact of Weather Parameters on Seasonal Incidence of Diseases and Enemies in Apis cerana F. Int.J.Curr.Microbiol.App.Sci. 7(12): 39-46. doi: https://doi.org/10.20546/ijcmas.2018.712.005 